\title{
THEORETICAL AND PRACTICAL ASPECTS REGARDING SOLVING CIVIL CASES IN AN OPTIMAL AND PREDICTABLE TIME
}

DOI: $10.47743 /$ rdc-2019-2-0001

PhD Associate Professor Mădălina DINU

"Titu Maiorescu" University, Faculty of Law

\section{Abstract}

The existence of a fair trial implies the granting of guarantees to the litigant in order to ensure compliance with the principle enshrined, first and foremost, at the constitutional level, but also in the Civil Procedure Code, in the Universal Declaration of Human Rights, the International Covenant on civil and political rights. The fair trial involves, on the one hand, the right of the litigant to a (independent and impartial) court, and on the other hand, the resolution of the case in an optimal and predictable time. In order to respect the optimal and predictable time frame for solving a civil case, the legislator has established a series of obligations, terms and penalties in case of non-compliance by the participants in the trial, but also by the court invested in solving the case.

Keywords: reasonable time limit; optimal and predictable time; guarantees; fair trial; trial duration estimate

The legislation does not define the notion of "fair trial", its understanding is related to the observance of other fundamental principles, respectively, the principle of the right to defense, the principle of equality of the parties in the trial, the adversarial principle ${ }^{1}$. The fair trial in the system of national law implies the existence of a single file to which all the procedural documents that are performed in the case are attached and which can be consulted by the parties or their representatives either on the day of the hearing, or prior to the hearing, in the archive, or through the electronic file, the court hearings are public, most of the procedural documents are written (the summons, the statement of defense, the counterclaim, the answer to the statement of defense, the motion to intervene filed by third parties in the case of voluntary intervention, or by the initial parties against third parties in the case of forced intervention). These features are

1 V.M. Ciobanu, in V.M. Ciobanu, M. Nicolae, The new civil procedure code commented and annotated, vol. I, Article 1-526, 2nd ed., Universul Juridic Publishing House, Bucharest, 2016.

STUDIES AND ARTICLES 
found in all continental law systems ${ }^{2}$, but, of course, with the existence of particularities depending on the legislation of each state.

A first guarantee of a fair trial is represented by the right of the litigant to access to a court of justice, by this understanding the right to file claims to the court, the right to obtain a resolution by the pronouncement of a court judgment, the right to obtain enforcement proceedings of an enforceable title ${ }^{3}$. The fundamental principle of the civil process, consisting of the right to a fair trial, in an optimal and predictable term, is enshrined in the Romanian Constitution, in the European Convention on Human Rights, in the Civil Procedure Code. Thus, according to Article 6 para. 1 of the Civil Procedure Code, "every person has the right to a fair trial for their case, in an optimal and predictable time, by an independent and impartial court established by the law. For this purpose, the court is obliged to order all the measures allowed by law and to ensure the speedy execution of the trial".

A second guarantee implies the resolution of the case in an optimal and predictable time. Thus, according to Article 6 para. 1, $1^{\text {st }}$ thesis of the Civil Procedure Code, "every person has the right to have their case judged in a fair, timely and predictable manner (...)", the competent court having the obligation to order all the measures allowed by law for the speedy execution of the trial, provisions that apply both in the phase of the trial and in the enforcement proceedings too, according to Article 6 para. 2 of the Civil Procedure Code.

Also, according to Article 21 para. 3 of the Romanian Constitution, which regulates the free access to justice of the citizens, "the parties have the right to a fair trial and to the settlement of cases within a reasonable time", and according to Article 6 of ECHR, "every person has the right to a fair and public trial held within a reasonable time". However, neither the Constitution nor the Convention define the time frame "reasonable", which will be assessed on a case-by-case basis, depending on the specific circumstances of the case. In this regard, in order to observe the reasonable time constraint, the criteria that are taken into account are the complexity of the case, the behavior of the parties, the compliance with the obligation of the court to resolve the case in a timely manner ${ }^{4}$. In the same sense, the Constitutional Court held that the phrase "'reasonable time' is a concept that is essentially variable, and its assessment is done with respect to the circumstances of the case, taking into account its complexity, the behavior of the claimants and of the competent authorities, as well as the stake of the litigation for the concerned parties (...). Moreover, the concept of 'reasonable term' must be seen from the perspective of both the citizen and the state and must be

\footnotetext{
2 D. Bogdan, Fair civil proceedings in ECHR case law, Vol. II. Equity stricto-sensu, Hamangiu Publishing House, Bucharest, 2011, p. 32.

${ }^{3}$ For more details on the right to a fair trial see I. Muraru, E.S. Tănăsescu (coord.), Romanian Constitution. Commented articles, $2^{\text {nd }}$ ed., revised and amended, C.H. Beck Publishing House, Bucharest, 2019, p. 159 et seq.

${ }^{4}$ B. Selejan-Guțan, in I. Muraru, E.S. Tănăsescu (coord.), Romanian Constitution. Commented articles, $2^{\text {nd }}$ ed., revised and amended, C.H. Beck Publishing House, Bucharest, 2019, p. 21.
} 
assessed and established from the concurrent analysis of the general interests of the society with those of the citizen" ${ }^{\prime}$.

From the analysis of the mentioned texts, apparently, it could be argued that there is a discrepancy between them, considering that the constitutional text and the European Convention on Human Rights establish the obligation to resolve the case within a reasonable time, while the text in the Civil Procedure Code uses the phrase "optimal and predictable time". The legislator's option to use the phrase "optimal and predictable term" in the Civil Procedure Code envisages that the Council of Europe, through the European Commission for the Efficiency of Justice has established, since 2004, that the term "reasonable" is the basis that separates the observance thereof from the non-observance and which cannot be considered as a sufficient result if it is achieved, establishing the judgment of each case in an "optimal and predictable term" as an objective for the legal system. Thus, the optimal time of solving a case involves the duration that ensures the best efficiency in achieving justice and its predictability gives the parties the opportunity to estimate the evolution of the procedural stages over time?. Moreover, the Constitutional Court held that "the optimal and predictable time frame is in fact a component of the reasonable term, not excluding it, but on the contrary assuming, among others, an optimal and predictable term. Thereby, if the term 'reasonable' refers to the limit between the observance/non-observance the right to a fair trial, the optimal and predictable one is a component that can be regulated at the infraconstitutional level, of the reasonable term" ${ }^{\prime}$. Therefore, we can conclude that the optimal and predictable time falls within the content of the reasonable term, the latter assuming the solution of the case in an optimal and predictable term.

To determine if the time limit for solving the case was optimal and predictable or at least reasonable (Article 21 para. 3 of the Constitution, Article 6 para. 1 of ECHR), the criteria that will be considered are the conduct of the parties, the complexity of the case (the number of parties, the administration of evidence that requires a prolonged time, a cross-border element etc.), the deadlines set and the measures ordered by the court. Given the fact that the civil trial begins on the day the court is vested (the date the court is notified), this is also the time from which the duration of the trial is analysed to determine whether the case was resolved in an optimal and predictable time, calculated until the time when the judgment remains final and in the case where the judgment is enforced, the time when the enforcement proceedings end (taking into consideration that the enforcement proceeding is also a phase of the civil process).

\footnotetext{
5 The decision of the Constitutional Court no. 80/2014, pnt. 59, available at https://lege5.ro/App/ Document/gm4tgojwg4/decizia-nr-80-2014-asupra-propunerii-legislative-privind-revizuirea-constitutiei-romaniei.

${ }^{6}$ V.M. Ciobanu, T.C. Briciu, C.C. Dinu, Civil procedural law, $2^{\text {nd }}$ ed., National Publishing House, Bucharest, 2018, p. 64.

${ }^{7}$ G. Boroi, M. Stancu, Civil procedural law, $5^{\text {th }}$ ed., revised and amended, Hamangiu Publishing House, Bucharest, 2020, pp. 15-16.

${ }^{8}$ The decision of the Constitutional Court no. 80/2014, pnt. 60, available at https://lege5.ro/App/ Document/gm4tgojwg4/decizia-nr-80-2014-asupra-propunerii-legislative-privind-revizuirea-constitutiei-romaniei.
}

STUDIES AND ARTICLES 
In the Romanian civil trial, solving the case within an optimal and predictable time frame also implies the intervention of the seised court, in the sense that the judge has the obligation to use all the means available and given to him by the legislator in order to resolve the case in a timely manner. In this respect, within the Civil Procedure Code, a series of obligations have been instituted both for the judge invested with the settlement of the case, but also for the parties and other participants in the civil process.

\section{A. Obligations established for the court, in order to resolve the case}

\section{in an optimal and predictable time}

A first obligation for the court is that, at the first court hearing at which the parties are legally summoned, the judge will estimate the length of the trial (according to Article 238 of the Civil Procedure Code ${ }^{9}$ ). However, for sound reasons ${ }^{10}$, the judge may reconsider the initially estimated length of the trial. Thus, the judge will estimate the duration of the trial during the first court hearing, after having previously discussed this aspect with the parties. The lack of the legally cited parties does not prevent the court from estimating the length of the trial, as, according to the provisions of Article 223 para. 1 of the Civil Procedure Code, the "lack of the legally cited party cannot prevent the trial of the case from taking place, unless otherwise provided in the law". We mention that the estimation of the trial takes into account the required time to solve the case at first instance, without taking into account the period elapsed before the first court hearing (the written stage) and the time required to solve the case in the appeals or in the enforcement proceedings ${ }^{11}$.

Regarding the criteria considered by the court in order to estimate the trial, they are not expressly provided, the text of Article 238 para. 1 of the Civil Procedure Code establishing as reference the "circumstances of the case". In this context, depending on the specific circumstances of the case (the number of parties, the object of the request for legal proceedings and/or the counterclaim, if it is formulated, the evidence pending to be administered according to those proposed by the applications), the court will estimate the duration of the process through a preparatory conclusion. The preparatory

\footnotetext{
${ }^{9}$ According to the legal text, at the first court hearing to which the parties are legally summoned, the judge, after listening to the parties, will estimate the time required for investigating the trial, taking into account the circumstances of the case, so that the trial will be settled in an optimal and predictable time, the estimated duration will be recorded in the conclusion and according to para. 2, for sound reasons, listening to the parties, the judge may reconsider the duration of the trial.

${ }^{10}$ As examples of reasonable grounds, we can mention the formulation of requests for intervention of third parties, the death of one of the parties during the civil process that may cause the legal suspension of the case under the conditions of Article 412 para. 1 pnt. 1 of the Civil Procedure Code.

${ }^{11}$ In the same sense, see I. Gîlcă, in V.M. Ciobanu, M. Nicolae (coord.), in The new civil procedure code commented and annotated. Vol. I. Articles 1-526, 2nd ed., Universul Juridic Publishing House, Bucharest, 2016, p. 813.
} 
nature of the conclusion allows the court to reconsider the estimated time given in the first hearing during the judicial investigation. The elements that can determine the reestimation of the duration of the trial can be determined by the formulation of the requests of voluntary intervention of the third parties, by the initial parties against the third persons or by the court ex officio under the conditions of Article 78 para. 1 and 2 of the Civil Procedure Code or by the necessity of administering some means of proof which involve a longer time (like the expertise or the administration of the evidence by rogatory letters), the suspension of the trial etc.

In some matters, the legislator has instituted that the judicial procedure must be carried out as a matter of urgency, which means that the terms of court will be shorter than those in a common law procedure. We mention, in this regard, the possession requests which, according to the provisions of Article 1004 para. 4 of the Civil Procedure Code, are judged urgently and above all, the requests regarding the evacuation from the buildings used or occupied without right are urgently solved according to Article 1042 para. 2 of the Civil Procedure Code, the presidential ordinance which, according to Article 999 para. 3 of the Civil Procedure Code, is judged urgently and above all, evidence whose administration requires a long time not being admissible. Related to the presidential ordinance, we mention that, according to Article 999 para. 3 final thesis of the Civil Procedure Code, "the provisions regarding the investigation of the process are not applicable", which means that, in this procedure, the rules of Article 238 of the Civil Procedure Code will not apply. As a result, the court has no obligation to estimate the length of the trial in the presidential ordinance.

A second guarantee to ensure compliance with the optimal and predictable timeframe for resolving the case is given by the procedural provisions governing the situations in which the parties can make a request to postpone the case and the censorship that can be exercised by the court on them. Thus, the request for postponement for lack of defense made by one of the parties can be ordered only exceptionally by the court, for sound reasons and which are not imputable to the party or its representative, according to the provisions of Article 222 para. 1 of the Civil Procedure Code. The sound reason is assessed on a case-by-case basis, which may be the inability of the lawyer to appear before the court (for objective reasons), the lack and the request of the other party to hire a lawyer in order to benefit from a qualified defense, the short period of preparation of the defense (for example, when the lawyer was hired on short notice before the court hearing) or objective reasons for the impossibility of appearing before the court by the party. Although the legal text does not limit the number of such requests, however, they should not lead to delay in the judgment. In this regard, the court may approve more than one request for non-defense, provided that the lack of defense is not attributable to the party or its representative. Also, at the request of the party, if the court rejects the request for non-defense, it will postpone the ruling to grant the possibility of the party whose request for non-defense has been refused to submit written conclusions, in accordance with the provisions 
contained in Article 222 para. 2 of the Civil Procedure Code. In this regard, the Constitutional Court also ruled that "the text of the law does not represent a restriction of the right to defense, nor does it violate the constitutional principles, but it is a measure of discouraging the exercising with bad faith the procedural rights through requests to postpone the trial in order to delay it and to enact justice. In addition, the jurisdiction established for the judge not to grant a deadline for lack of defense, (however, at the request of the party the court will postpone the decision so that it can formulate and submit the written conclusion to the case file) or to grant a single deadline for this purpose, involves the responsibility of the judge in carrying out the act of justice (...)"12.

Given that the observance the optimal and predictable time frame for resolving a case involves avoiding the causes of deferral that are unfounded, in the event that the applications for deferral are approved, leading to the unnecessary extension of the civil process, a complaint can be made against delaying the process, by which one of the parties may challenge the delays granted. Thus, according to the provisions of Article 522 para. 1 of the Civil Procedure Code, "either party, as well as the prosecutor participating in the trial, can appeal by invoking the violation of the right to the settlement of the trial within an optimal and predictable time, in order to request the legal measures to be taken so that this situation can be removed".

The time limit set by the legislator for drafting and motivating the decision is another guarantee for observing the optimal and predictable time frame for giving a resolution to the case. Thus, according to the provisions of Article 426 para. 5 of the Civil Procedure Code, the deadline for drafting and signing the court decision is no more than 30 days from the ruling date. In duly justified cases, this period may be extended by 30 days at most twice. The separate opinion of the judge remaining in the minority, as well as, when appropriate, the competing opinion is drafted and signed within the same time frame. The law establishes a maximum period of 90 days for the drafting of the court decision, and the non-observance of this time limit will attract the disciplinary sanction of the judge, regardless of the reason for the extension of the maximum time limit of 90 days, this sanction has as a basis Article 99 letter r) of Law no. 303/2004 which establishes as a disciplinary offense "the failure to draft or sign the judgments or judicial documents of the prosecutor, for imputable reasons, within the time frames provided by law", among others. However, the judge could be exempted from this liability by proving exceptional circumstances that prevented the judge from observing even this extended term ${ }^{13}$. Of course, in addition to attracting the judge's responsibility,

${ }^{12}$ Decision no. 490 of July $8^{\text {th }}, 2006$, of the Constitutional Court, published in the Official Gazette of Romania no. 587 of June $6^{\text {th }}, 2006$, by which the Court rejected the exception of unconstitutionality of the provisions of Article 156 of the old regulations, now Article 222 of the Civil Procedure Code.

13 T.C. Briciu, M. Stancu, C.C. Dinu, Gh.L. Zidaru, P. Pop, Comments on the amendment of the new civil procedure code by Law no. 310/2018. Between the desire of functionality and the tendency to restore, available at https://www.juridice.ro/essentials/2901/comentarii-asupra-modificarii-noului-cod-de-procedura-civila-prin-legeanr-310-2018-intre-dorinta-de-functionalitate-si-tendinta-de-restauratie.

CONSTITUTIONAL LAW REVIEW 
Theoretical and practical aspects regarding solving civil cases...

the party has at hand the appeal procedure regarding the delay of the judgment, in relation to the provisions of Article 522 para. 2 pnt. 1 of the Civil Procedure Code, according to which, the appeal procedure can also be used when "the law establishes a deadline for the completion of a procedure, of pronouncing or motivating a decision, but this deadline has been reached without result".

\section{B. Obligations and time limits set up for the parties and the participants}

\section{in the civil process in order to solve a case in an optimal}

\section{and predictable time}

In what concerns the parties (the applicant, the defendant and the third intervening parties, under the conditions of the law), in order to comply with the optimal and foreseeable time frame for resolving the case, the legislator has instituted numerous deadlines, forcing the parties to carry out the procedural documents within them. Thus, according to the provisions of Article 201 para. 1 of the Civil Procedure Code, the defendant is obliged to submit a statement of defense to the writ of summons made by the claimant within 25 days from the date of its receipt, under the sanction provided in Article 208 of the Civil Procedure Code, respectively the lapse of the right to invoke relative exceptions and to propose evidence. In addition, Article 204 para. 1 of the Civil Procedure Code establishes the possibility for the claimant to modify the request for a trial before the first time limit in which he is legally summoned before the first court. At the same time, the relative nullity is invoked at the deadline in which the irregularity was committed or at the immediate deadline in which the party is legally cited, according to Article 178 para. 3 letter b) of the Civil Procedure Code. The third voluntary intervener may make the request for intervention until the closing of the debates before the first court (Article 62 para. 2 of the Civil Procedure Code) or with the express agreement of the other parties until the closing of the debates before the appeal court (Article 62 para. 3 of the Civil Procedure Code) - exceeding the deadlines entails the rejection of the request for intervention, but the third party has the possibility to file his claim separately by introducing a request for bringing legal action against the initial parties. With regard to the forced intervention requests (the request for the prosecution of other persons who could claim the same right as the plaintiff, the request for a guarantee call), these can be formulated by the plaintiff or the main voluntary intervener until the trial before the first court is completed (Article 68 para. 2 of Civil Procedure Code, Article 73 para. 2 of Civil Procedure Code) and if they are formulated by the defendant, he has to do it within the time limit for filing a statement of defense before the first court, and if a statement of defense is not mandatory, at the 


\section{Mădălina DINU}

latest at the first court hearing (Article 68 para. 3 of the Civil Procedure Code, Article 73 para. 3 of the Civil Procedure Code), the defendant being able to formulate the request for showing the right holder at the same time (Article 76 of the Civil Procedure Code). In the same sense, if the party, without good reason, refuses to appear for the cross-examination or does not appear for the administration of the examination, although was legally summoned or present at the time at which this evidence was approved, knowing the deadline, in accordance with the provisions of Article 229 para. 2 pnt. 3 of the Civil Procedure Code, the court may consider these circumstances as a full confession in favor of the person who proposed the examination or a beginning of evidence for the one who proposed the examination, in which case both the evidence with witnesses and other evidence, including the presumptions, may be admitted alongside the previous evidence.

Regarding the other participants in the civil process, in their case the legislator has set terms and sanctions in case of non-compliance. Thus, if the evidence analysis is ordered alongside an expertise, the expert report must be submitted to the case file at least 10 days prior to the deadline set for trial, with the possibility of the time frame being shortened in urgent cases, according to the provisions of Article 336 para. 1 of the Civil Procedure Code. If the expert report has been submitted within the deadline, the parties are not entitled to obtain a postponement for its study, however, if the report was submitted less than 10 days before the deadline set for trial, the parties have the right to request the court to grant a short time limit in order to study it (if the court does not grant the term, the procedural document is null, but the nullity is conditioned by the existence of an injury, with all the consequences that result from it). If the expert report is filled within a shorter time limit than the one provided by law, this irregularity must be invoked by the interested party at the trial hearing immediately following the submission of the report. If for the first hearing that followed the submission of the expert report, the party was legally summoned, but did not appear in court nor made a written request to postpone the judgment in order to study the administered evidence, the irregularity consisting in the non-observance of the legal time limit of submission of the expert report is elapsed, the interested party being deprived of the right to invoke it later ${ }^{14}$. Regarding the evidence with witnesses, against the witness who is missing from the first summons, the court can issue a warrant of arrest of defaulting witness, and, if there is urgency, the warrant of arrest for defaulting witnesses can be used even at the first time limit. The court may fine the witness who, although legally summoned, does not appear or, although he appears in court, refuses to testify. If, after issuing the warrant of arrest of defaulting witnesses, the witness cannot be found or does not

14 The Bucharest Court of Appeal, The Third Civil Chamber, minors and family, decision no. 93 of January 23 $3^{\text {rd }}$ 2007, www.idrept.ro. 
Theoretical and practical aspects regarding solving civil cases...

appear before the court, the court can proceed to the trial of the case, according to the provisions of Article 313 para. 3 of the Civil Procedure Code.

The establishment of these deadlines and the sanctions that can intervene as a result of their non-observance aims to ensure the resolution of the case in an optimal and predictable time. Of course, subjective elements such as the guilty conduct of the parties or other participants in the civil process and the lack of sanctions applied by the court in this regard or objective elements such as the number of parties, the complexity of the case, the occurrence of the procedural incidents (such as, for example, the legal suspension of the case, due to the death of one of the parties, the closure of the mandate or function of the guardian or trustee under the conditions of Article 412 of the Civil Procedure Code), they are often elements that determine that the observance of the optimal and predictable time frame of settlement of a civil case is difficult to achieve. 